\title{
UPAYA PENINGKATAN HASIL BELAJAR BAHASA INGGRIS MELALUI PENERAPAN STRATEGI PEMAHAMAN BACAAN DIRECTED READING THINKING ACTIVITY (DRTA) PADA SISWA KELAS XI SMA NEGERI 2 BINJAI
}

\author{
Jeniwati ${ }^{1}$, Busmin Gurning ${ }^{2}$ \\ SMA Negeri 2 Binjai $^{1}$, Pascasarjana Universtas Negeri Medan ${ }^{2}$ \\ jeniwari@gmail.com ${ }^{1}$
}

\begin{abstract}
Abstrak: Penelitian ini bertujuan untuk: (1) Meningkatkan pemahaman bacaan siswa kelas XI SMA dengan menggunakan strategi Directed Reading Thinking Activity (DRTA), (2) Meningkatkan keaktifan siswa setelah mengikuti pembelajaran pemahaman bacaan yang menggunakan strategi DRTA. Hasil analisis data menunjukkan bahwa terdapat peningkatan yang signifikan dalam pemahaman bacaan siswa. Ini dapat dilihat dari rata-rata hasil test siswa; Nilai rata-rata kelas pada Pre-test adalah 65,92, nilai rata-rata kelas pada siklus I adalah 72,19 dan nilai rata-rata kelas pada siklus II adalah 78,33 . Faktor utama dari peningkatan hasil belajar ini adalah ketertarikan siswa dalam pembelajaran pemahaman membaca dengan penerapan strategi DRTA Berdasarkan data ini, maka dapat disimpulkan bahwa pembelajaran dengan menggunakan strategi DRTA dapat meningkatkan pemahaman bacaan siswa dan proses pembelajaran lebih menyenangkan. Diharapkan hasil penelitian ini bisa menjadi masukan bagi guru-guru bahasa Inggris dalam memilih dan mengembangkan media dan strategi pembelajaran yang tepat terkait dengan pembelajaran ketrampilan membaca (Reading Skill) di Sekolah Menengah Atas.
\end{abstract}

Kata Kunci: bahasa inggris, strategi pemahaman bacaan directed reading thinking activity

Abstract: This study aimed to: (1) Improve reading comprehension class XI student of SMA using strategies Directed Reading Thinking Activity (DRTA), (2) Increase the involvement of the student after attending a reading comprehension lesson using the strategy DRTA. The results of data analysis showed that there were significant increases in students' reading comprehension. It can be seen from the average student test results; The average value of the pre-test grade was 65.92, the average value of the class in the first cycle was 72.19 and the average value of the class on the second cycle is 78.33. The main factor of this learning outcome is student interest in learning to read with comprehension strategy implementation DRTA Based on this data, it can be concluded that learning by using strategies DRTA can improve students' reading comprehension and learning process more fun. We hope this research can be input for teachers of English in selecting and developing media and appropriate learning strategies related to learning reading skills (Reading Skill) in high school.

Keywords: English, reading comprehension strategies directed reading thinking activity

\section{PENDAHULUAN}

Bahasa Inggris merupakan alat untuk berkomunikasi secara lisan dan tulis. Berkomunikasi adalah memahami dan mengungkapkan informasi, pikiran, perasaan, dan mengembangkan ilmu pengetahuan, teknologi dan budaya. Kemampuan berkomunikasi dalam pengertian yang utuh adalah kemampuan berwacana, yakni kemampuan memahami dan/atau menghasilkan teks lisan dan/atau tulis yang direalisasikan dalam empat keterampilan berbahasa, yaitu, mendengarkan, berbicara, membaca, dan menulis. Keempat keterampilan inilah yang digunakan untuk menanggapi atau menciptakan wacana dalam kehidupan bermasyarakat. Oleh karena itu, mata pelajaran bahasa Inggris diarahkan untuk mengembangkan keterampilan-keterampilan tersebut agar lulusan mampu berkomunikasi dan berwacana dalam bahasa Inggris dalam tingkat literasi tertentu.

Tujuan pengajaran bahasa asing pada umumnya membuat peserta didik memiliki kemampuan berkomunikasi dengan penutur asli dan bahasa target atau setidaknya dapat berkomunikasi secara lisan dengan sesama peserta. Tetapi tujuan ini dapat disesuaikan dengan kebutuhan Institusi penyelenggara 
pendidikan (Depdiknas, 1994:2). Pengajaran Bahasa Inggris di tingkat SMA berlandaskan pada empat komponen, yaitu reading, speaking, listening, writing (Anonimous, 1994:2). Di antara komponen ini reading (membaca) memiliki implikasi yang paling kompeten dalam membentuk peserta didik menjadi manusia yang berilmu pengetahuan dan menguasai teknologi. Pesatnya perkembangan ilmu pengetahuan dan teknologi di sisi lain juga menuntut masyarakat yang gemar membaca. Proses belajar yang efektif antara lain juga dilakukan melalui membaca. Dengan membaca, terutama buku yang memiliki arti yang penting bagi seorang individu, seseorang dapat memperoleh informasi dan pengetahuan sekaligus dapat mengembangkan daya imajinasi dan daya pikir dari informasi yang diperolehnya. Christopher Morley seorang penulis dari Amerika seperti yang dipaparkan Kompas dalam rubrik Ragam (2006:46) melukiskan hal ini dengan ilustrasi peristiwa ketika seseorang menjual sebuah buku kepada orang lain, orang tersebut tidak hanya menjual sebuah benda seberat 12 ons yang terdiri atas kertas, tinta, dan lem, tetapi berarti ia juga telah menjual sebuah hidup baru untuk sipembeli.

Strategi dalam pandangan Rahim (2005:36) adalah ilmu dan kiat di dalam memanfaatkan segala sumber yang dimiliki dan/atau yang dapat dikerahkan untuk mencapai tujuan yang telah ditetapkan. Dalam usaha memperoleh pemahaman terhadap teks, pembaca menggunakan strategi tertentu. Pemilihan strategi berkaitan erat dengan faktorfaktor yang terlibat dalam pemahaman yaitu pembaca teks dan konteks.

Di dalam teori membaca dikenal beberapa strategi membaca. Salah satu strategi membaca yang diduga dapat memaksimalkan belajar siswa dan berorientasi pada siswa adalah strategi Directed Reading Thinking Activity (DRTA). Strategi DRTA memberikan kebebasan dan suatu peran aktif pada siswa dengan cara menarik minat dan perhatian mereka dengan memaparkan kepada siswa tujuan membaca sebelum kegiatan membaca dimulai. Menurut Stauffer (1990) Sebagaimana yang disitasi Rahim (2005:47) Strategi DRTA memfokuskan keterlibatan siswa dalam berpikir tentang bacaan dan keterlibatan siswa dengan teks dengan cara memprediksi dan membuktikannya ketika mereka membaca. Peran guru pada strategi ini hanya sebagai fasilitator. Landasan filosofis strategi ini adalah untuk memotivasi, menarik perhatian siswa dan membuat siswa berkonsentrasi dapat dengan cara melibatkan mereka secara intelektual dengan mengajak siswa berpikir, serta mendorong mereka merumuskan pertanyaan dan hipotesis, memproses informasi, dan mengevaluasi solusi sementara dengan cara melibatkan siswa dengan teks melalui prediksi atau pemikiran siswa dan membuktikannya ketika siswa membaca. Strategi DRTA yang akan dikembangkan dalam penelitian ini diduga dapat lebih mengoptimalkan kemampuan siswa dalam memahami materi bacaan dan dapat pula menarik minat dan perhatian siswa melalui peranan guru sebagai motivator yang kreatif dalam upayanya meningkatkan motivasi siswa. Salah satu caranya dengan memperjelas tujuan yang ingin dicapai, dengan semakin jelas tujuan pembelajaran dan pentingnya informasi dari materi bacaan, maka motivasi dan minat siswa akan semakin kuat. Membangkitkan minat siswa akan dapat ditumbuhkan jika ia dapat menangkap bahwa materi pelajaran itu berguna bagi kehidupannya. Oleh karena itu perlu dilakukan penelitian mengenai upaya peningkatkan hasil belajar bahasa Inggris melalui penerapan strategi pemahaman bacaan DRTA pada siswa kelas XI SMA Negeri 2 Binjai.

Pemahaman mengenai belajar dapat dinilai dari beberapa definisi yang telah dirumuskan oleh para ahli pendidikan yang didasarkan pada hasil analisa dan sudut pandang mengenai makna belajar. Menurut Sardiman (2009:20-21) dalam pengertian luas, belajar dapat diartikan sebagai kegiatan psikofisik menuju ke perkembangan pribadi seutuhnya. Kemudian dalam arti sempit, belajar dimaksudkan sebagai usaha penguasaan materi ilmu pengetahuan yang merupakan sebagian kegiatan menuju terbentuknya kepribadian seutuhnya. Dengan kata lain belajar pada hakikatnya merupakan usaha yang dilakukan untuk memenuhi pengetahuan yang bertujuan untuk membentuk

Berkenaan dengan defenisi belajar secara formal, Gagne (1983:81), Gagne dan Briggs (1979:43) dalam Gredler (1994:187) mendefenisikannya sebagai seperangkat proses kognitif yang mengubah sifat stimulasi dari lingkungan menjadi beberapa tahapan pengolahan informasi yang diperlukan untuk memperoleh kapabilitas yang baru. Belajar terjadi ketika seseorang memperoleh kemampuan tertentu untuk melakukan sesuatu. 
Kemampuannya tidak dapat diamati, hanya dapat terlihat dari perilaku si belajar dalam unjuk kerja, dengan demikian barulah dapat disimpulkan bahwa si belajar telah memiliki kemampuan yang telah dipelajarinya. Kejadian internal yang dialami oleh seseorang dalam proses belajarnya dijelaskan dalam rangkaian sembilan fase oleh Gagne (1988:246); Driscoll (1994:351) yang dimulai dengan perhatian (reception, gaining attention, alertness), si belajar khusus memperhatikan hal yang akan dipelajari. Fase kedua menyadari tujuan belajar (motivation, expectancy), si belajar sadar akan tujuan instruksional dan bersedia melibatkan diri. Fase ke tiga menggali (retrieval to working memory), si belajar mengingat kembali dari ingatan jangka panjang apa yang sudah diketahui/dipahami/dikuasai tentang apa yang sedang dipelajari. Fase ke empat berpresepsi selektif (selective perception), si belajar mengamati unsur-unsur dalam perangsang yang relevan dengan apa yang sedang dipelajari. Fase ke lima mengolah informasi (encoding, entry to storage), si belajar memberikan makna pada pola perseptual dengan membuat informasi yang bermakna dengan menghubungkan informasi lama yang digali dari ingatan jangka panjang. Fase ke enam, menggali informasi (responding to question or task), si belajar membuktikan melalui suatu prestasi atau unjuk kerja kepada guru dan dirinya sendiri bahwa apa yang dipelajarinya telah dikuasai. Fase ke tujuh, mendapatkan umpan balik (feedback, reinforcement), si belajar mendapat penguatan dari guru kalau prestasi atau unjuk kerjanya tepat, dan mendapat koreksi kalau prestasi atau unjuk kerjanya salah. Fase ke delapan, penilaian kemampuan (assessing performance) pengetahuan baru sebagai respon sebaiknya dapat ditampilkan si belajar perunit atau perbab. Fase terakhir, memantapkan hasil belajar (frequent retrieval tranfer), si belajar mengerjakan berbagai tugas untuk mengakarkan hasil belajar, si belajar mengadakan transfer belajar, siswa mengulangngulang kembali.

Pakar teknologi pendidikan, Gagne, Briggs dan Wager (1993:11) dalam Prawiradilaga (2007:24) menyempurnakan pandangan ini dengan menyatakan bahwa proses belajar seseorang dapat dipengaruhi oleh faktor internal peserta didik itu sendiri dan faktor eksternal, yaitu pengaturan kondisi belajar. Proses belajar terjadi karena sinergi memori jangka pendek dan jangka panjang diaktifkan melalui penciptaan faktor eksternal, yaitu pembelajaran atau lingkungan belajar. Melalui inderanya, si belajar dapat menyerap materi secara.

Berdasarkan proses belajar yang dilakukan maka menghasilkan suatu hasil/prestasi belajar. Gagne (1988:67) menyebutkan bahwa hasil belajar merupakan kapasitas terukur dari perubahan individu yang diinginkan berdasarkan ciri-ciri atau variable bawaannya melalui perlakuan pengajaran tertentu. Reigeluth sebagaimana dikutip Keller dalam Uno (2009:137), menyebutkan bahwa hasil belajar adalah semua efek yang dapat dijadikan sebagai indikator tentang nilai dari penggunaan suatu metode di bawah kondisi yang berbeda.

Mayer (1992) dalam Reigeluth (1999:143) mengemukakan adanya tiga jenis hasil belajar berdasarkan pandangan bahwa proses belajar terjadi jika si belajar menguatkan atau melemahkan gabungan antara stimulus dan respon. Belajar adalah pemerolehan pengetahuan karena belajar benar-benar terjadi jika si belajar dapat menempatkan informasi baru di dalam memori jangka panjangnya. Belajar adalah mengkonstruksikan pengetahuan dalam kerangka memorinya, meskipun hasilnya tidak berupa perilaku. Jenis belajar yang terakhir cenderung didefenisikannya sebagai tidak terjadinya proses belajar jika si belajar gagal memperhatikan informasi yang masuk dan relevan dengan informasi lama yang telah ada dalam sturktur kognitifnya.

Molenda (2005:17) lebih cenderung menyimpulkan hasil belajar bergantung pada seberapa baik metode pembelajaran direncanakan dan diimplementasikan. Joyce dan Weil (1996:142) lebih berfokus pada bagaimana setelah terjadi proses belajar dapat terjadi pula peningkatan komitmen dan rasa mawas diri seseorang melalui belajar berpikir dan menganalisa perkembangan sosial si belajar. Jika berfokus pada pembelajaran bahasa asing khususnya pembelajaran di dalam kelas, Allwright dan Bailey (1991:23) berpendapat bahwa ada tiga hasil belajar yang disebutnya input, practise opportunities, dan receptivity. Input atau masukan berupa informasi yang dapat dipahami, interaksi dan kebudayaan si belajar Practice Opportunities, kesempatan untuk mempraktekan apapun yang sedang diusahakannya untuk dipelajari. Apapun yang direncanakan oleh guru untuk membangun suasana kondusif di dalam kelas dapat 
menghasilkan kesediaan menerima berupa sikap yang aktif dan terbuka dan adanya keinginan untuk menerima bahasa dan budaya yang sedang dipelajarinya (Allwright dan Bailey 1991: 1135).

Membaca didefenisikan Buzan (2002:38) sebagai hubungan timbal balik individu secara total dengan informasi simbolik. Menurutnya membaca meliputi tujuh langkah, yaitu: pengenalan (pengetahuan pembaca mengenai simbol abjad). Asimilasi (sinar dipantulkan dari kata dan diterima oleh mata kemudian dikirim lewat syaraf mata ke otak), intra-integrasi (penghubung semua bagian informasi yang sedang dibaca dengan seluruh bagian lain yang layak). Ekstra-integrasi (meliputi analisis, kritik, apresiasi, seleksi, penolakan, dan melibatkan seluruh pengetahuan yang dimiliki), penyimpanan (penyimpanan informasi dasar yang disertai dengan mengingat). Mengingat adalah memperoleh kembali sesuatu yang dibutuhkan, adalah langkah sebelum komunikasi, penggunaan dimana informasi segera atau akhirnya ditaruh yang meliputi subdivisi yang paling penting, yaitu berpikir. Pendapat senada dipaparkan oleh Herwono (2005:72) dalam bukunya Quantum Reading, membaca dapat mengintegerasikan diri kita, karena dengan membaca seseorang harus mencerna apa maksud sebuah kata, kalimat, dan alinea. Seseorang harus berpikir, mengolah apa saja yang diterima dari kalimat yang dibacanya.

Rakhmat (2005:267) berpendapat, pada anak-anak membaca mengembangkan perbendaharaan kata dan koneksi-koneksi baru pada pada sistem auditifnya. Bagi orang dewasa, membaca adalah latihan mental untuk mempelajari hal-hal baru, sekaligus mengembangkan apa yang disebut Given ( disitasi oleh Rakhmat,2005) sebagai lima sistem belajar: Emosional, Sosial, Kognitif, Fisikal, dan Reflektif. Dengan membaca, seseorang mengembangkan kemampuan empatinya untuk merasakan apa yang dirasakan orang lain; memasuki ruang sosial dan dan berinteraksi dengan dunia-dunia baru yang lebih luas; menajamkan kemampuan membaca persoalan, mendorong perencanaan untuk melakukan ekplorasi dan eksprimen. Membaca menurut para peneliti neurologis sangat menguntungkan otak karena membaca sangat merangsang kedua belahan otak,dan juga sistem limbik. Membaca apapun isinya memerlukan keterlibatan aktif pikiran dan imajinasi. Membaca menuntut pembacanya untuk membentuk strategi membaca yang sesuai, memonitor pemahamannnya, dan menilai hasilnya.

Membaca tanpa memahami atau yang disebut Hernowo $(2004 ; 48)$ mengikat makna adalah perbedaan membaca pemahaman dan membaca hanya huruf-huruf yang ada di buku atau teks tanpa dapat membaca pikiran si pengarangnya. Sementara menurut pendapat Effendi (2005:49) pemahaman membaca membutuhkan kemampuan menganalisa kode pesan, memahami pikiran si penulis.

Ahli membaca Steve Stahl (2002) sebagaimana disitasi Santrock ( 2007:420) percaya bahwa tujuan instruksi membaca seharusnya dapat membantu murid untuk: (a) menggali kata secara otomatis, (b) memahami teks, (c) termotivasi untuk membaca dan mengapresiasi membaca. Tujuan-tujuan tersebut saling terkait saling terkait satu sama lain. Dalam usaha memperoleh pemahaman terhadap teks, pembaca (siswa) menggunakan strategi tertentu. Pemilihan strategi berkaitan erat dengan faktor-faktor yang terlibat dalam pemahaman, yakni pembaca teks dan konteks. Strategi pemahaman bacaan pada dasarnya mengambarkan bagaimana pembaca memproses bacaan sehingga ia memperoleh pemahaman terhadap bacaan tersebut. Hakekat pemahaman sendiri menurut Thorndike sebagaimana disitasi oleh McNeil (1992:16) pemerolehan pandangan dan manipulasi pandangan. Pemahaman berorientasi proses yang melibatkan aktivitas mental pembaca ketika berinteraksi dengan teks tertulis, pengukuran dilakukan dengan meminta pembaca dengan menjawab pertanyaan. Dengan kata lain memahami bacaan dapat didefinisikan sebagai kemampuan menjawab pertanyaan pemahaman yang sesuai.

Tes hasil belajar dalam penelitian ini terdiri dari kawasan kognitif. Keterampilan intelektual, strategi kognitif, dan informasi verbal hasil belajar Gagne dapat dikelompokkan dalam ranah kognitif Bloom. Ranah kognitif menurut Reigeluth dan Moore (1995:52) menguraikan begaimana si belajar mengingat dan mengenal pengetahuan dan mengembangkan kemampuan intelektual dan keterampilannya. Ranah kognitif Bloom; Pengetahuan (mengetahui dan mengingat), Pemahaman (menterjemahkan, menafsirkan, memberikan contoh, membandingkan, dan menjelaskan), Penerapan (mengaplikasikan konsep, memisahkan atau menentukan mana 
yang sesuai), Analisis (merincikan materi menjadi bagian-bagian kecil, menentukan deskripsi tertentu mana yang menentang atau mendukung, menyusun bukti deskripsi). Disisi lain tingkat pemahaman bacaan menurut Sofa (2008) terdiri dari pemahaman Literal (pembaca memahami makna apa adanya, sesuai dengan simbol bahasa yang ada dalam bacaan, tidak menuntut jawaban yang berada diluar teks, seluruh jawaban dapat ditemukan didalam teks), dapat dikelompokkan dalam ranah pengetahuan (C1), sementara tingkat pemahaman Interpretasi (menangkap pesan tersirat, memerlukan kemampuan dan pengalaman yang dimiliki si pembaca tentang hal-hal yang berhubungan dengan masalah yang dapat muncul berdasarkan teks bacaan) dapat dikelompokkan dalam ranah pemahaman (C2).

Miarso (2004:530) mengatakan strategi pembelajaran adalah pendekatan menyeluruh pembelajaran dalam suatu sistem pembelajaran, yang berupa pedoman umum dan kerangka kegiatan untuk mencapai tujuan umum pembelajaran, yang dijabarkan dari pandangan falsafah dan atau teori belajar tertentu. Miarso (2004) mendukung pendapat Romizowski (1981) yang membagi dua strategi dasar berdasarkan pandangan strategi pembelajaran sebagai suatu pendekatan menyeluruh, yaitu ekspositori (penjelasan) dan discovery (penemuan).

Senada dengan Miarso (2004), Gulo (2005:12) menyatakan strategi belajar mengajar adalah rencana dan cara-cara membawakan pengajaran agar segala prinsip dasar dapat terlaksana dan segala tujuan pengajaran dapat dipakai secara efektif. Strategi belajar mengajar yang membelajarkan dan peserta didik dan mengharapkan peserta didik dapat memproses sendiri penemuannya melalui stimulasi dan pengarahan dari guru serta dilihat dari cara memproses penemuan, terbagi dua, ekspositori dan strategi discovery. Menurutnya, strategi dapat digolongkan dalam dua kutub yang ekstrem. Satu sisi siswa terlibat secara maksimal dalam usaha mencari dan menemukan, strategi ini disebut strategi inkuiri dan discovery, sedangkan pada sisi yang lain strategi yang disebut strategi ekspositori, keterlibatan siswa sangat terbatas pada menerima informasi. Dick, Carey dan Carey (2005) menyatakan bahwa strategi pembelajaran menjelaskan komponenkomponen umum dari seperangkat bahan pembelajaran dan prosedur yang akan digunakan dalam mengelola kegiatan pembelajaran untuk menghasilkan hasil belajar tertentu. Strategi pembelajaran bukanlah sekedar penjelasan sederhana berkenaan dengan materi yang akan disampaikan kepada siswa. Menurut Suparman (1997:25) strategi pembelajaran berkenaan dengan pendekatan pengajaran dalam mengelola kegiatan pembelajaran untuk menyampaikan materi secara sistematik, sehingga tercapai kemampuan yang diharapkan. Strategi pembelajaran mengandung empat unsur, yaitu : (1) urutan kegiatan pembelajaran, yaitu urutan kegiatan pengajar dalam menyampaikan isi pelajaran kepada siswa (2) metode pembelajaran , yaitu cara mengajar mengorganisasikan materi pelajaran agar terjadi proses belajar secara efektif dan efisien, (3) media pembelajaran yaitu peralatan dan bahan pembelajaran yang digunakan pengajar dan siswa dalam kegiatan pembelajaran, (4) waktu yang digunakan pengajar dan siswa dalam menyelesaiakan setiap langkah dalam tiap pembelajaran.

Kamus pendidikan yang dikompilasi oleh Cooper (2004:135) mendefinisikan strategi pembelajaran sebagai sebuah metode pembelajaran yang didasari oleh pengajaran dan strategi kognitif dalam rangka mencapai penyelesain tugas yang berhasil. G.Ellis dan Sinclair (1989) dalam Nunan (1991:169) mengkatagorikan strategi berdasarkan pemusatan keterampilan makro; listening (mendengarkan), speaking (berbicara), reading (membaca), atau writing (menulis). Kesemuanya membutuhkan pemahaman termasuk didalamnya vocabulary (perbendaharaan kosa kata) dan grammar (tata bahasa).

Skimming dan scanning menurut Grellet (1981) seperti yang disitasi oleh Omaggio (1986:151) adalah cara-cara seseorang membaca, pada saat skimming si pembaca menggerakkan matanya melewati kalimat demi kalimat yang terdapat dalam teks yang dibacanya dan pada saat bersamaan mengambil kesimpulan dari isi teks tersebut. Jika pembaca secara cepat mencari beberapa potongan informasi penting yang terdapat dalam teks yang di bacanya maka si pembaca menggunakan cara yang disebut dengan scanning.

Pada saat guru melakukan proses pembelajaran mata pelajaran bahasa Inggris 
dengan materi pokok Reading, pada dasarnya bukanlah mengajar memahami bacaan tetapi lebih pada bagaimana seorang guru dapat membantu siswanya mengoptimalkan keterampilan yang dibutuhkan atau yang terlibat dalam kegiatan membaca (Broughton et al, 1978). Prinsip dasar pembelajaran membaca adalah si pembaca harus diberikan tujuan umum atau petunjuk sebelum membaca. Siswa sebagai pembaca memiliki beberapa strategi yang lazim digunakan, seperti menebak secara kontekstual (contextual guessing), mengidentifikasikan kategori kata secara grammatik (identification of grammatical categories of words), pengenalan kognasi (recognation of cognates), memanfaatkan illustrasi dan kosa kata kunci (use of cues from illustrations and glosses). Jika guru mengajarkan pemahaman bacaan dan membantu siswanya mengoptimalkan keterampilan yang dibutuhkan dalam kegiatan membaca, guru seyogianya menyiapkan strategi untuk membangun "content-area reading comprehension" yang lazim disebut before reading (kegiatan sebelum membaca), whilst reading (saat membaca), dan setelah membaca (after reading).

Strategi diperlukan untuk mencapai hasil belajar yang optimal. Menurut Maisah dan Yamin (2009:220) penilaian dilakukan untuk menentukan apakah peserta didik telah berhasil menguasai suatu kompetensi yang mengacu pada indikator atau tidak. Penilaian dilakukan pada waktu pembelajaran atau setelah pembelajaran berlangsung. Sebuah indikator dapat dijaring dengan beberapa dengan beberapa soal/tugas. Penilaian yang dimaksud dapat ditentukan dalam bentuk angka-angka atau nilai yang diberikan kepada siswa setelah menjalani proses pembelajaran. Biasanya diukur dengan menggunakan tes formatif atau tes sumatif.

Pada model strategi interaktif, teks bacaan hanya menyediakan arahan bagi pembaca, Pembaca menemukan dan membangun sendiri makna teks berdasarkan pengetahuan awal si pembaca. Model ini menekankan arti penting latar belakang pengetahuan pembaca dan struktur pengetahuan awal si belajar sebagai pembaca. Strategi yang dikembangkan oleh Novak dan Gowin (1984) dalam Oxford (1990:241) dianggap sangat bermanfaat dalam kegiatan pre-reading untuk memahami teks bacaan. Memanfaatkan struktur pengetahuan awal dengan cara memperluas jaringan kata atau konsep dapat membantu siswa membuat hubungan yang penting dan memperkaya situasi komunikasi secara kontekstual.

Strategi DRTA dikembangkan oleh Stauffer (dalam Rahim 2005:47) yang diarahkan untuk mencapai tujuan umum dan memfokuskan keterlibatan siswa dengan teks melalui kegiatan memprediksi dan membuktikan prediksinya disaat mereka membaca. Guru mengamati siswanya ketika mereka membaca, dalam rangka mendiagnosis kesulitan dan menawarkan bantuan ketika siswa sulit berinteraksi dengan bahan bacaan.

Mengetahui tujuan melakukan sesuatu membuat siswa menempatkan energi mereka di saluran dan arah yang tepat. Guru dapat membantu dengan membiarkan siswa belajar sebelum mengerjakan tugas tersebut. Menurut Hyland (1993:109) tujuan membaca teks bacaan tertentu adalah hal yang terpenting untuk menentukan strategi membaca. Keikutsertaan emosional dapat dibangun dengan memaparkan tujuan dan mengetahui manfaat materi yang sedang dipelajari. Tanpa keikutsertaan emosional tidak akan ada belajar. De Porter dan rekan-rekannya (2003:202) dalam bukunya Quantum Teaching menyatakan dengan menyatakan tujuan, komunikasi antara siswa dan guru akan terjalin baik. Pada kegiatan membaca siswa dapat mencari tujuannya membaca dengan mempelajari situasi dan jenis teks yang dibacanya.

Pada saat siswa memprediksi siswa dituntut untuk berpikir, siswa dibimbing untuk menemukan sendiri konsep yang harus dikuasainya melalui proses dialogis yang terus menerus dengan memanfaatkan pengalaman siswa. Langkah kegiatan pembelajaran ini jika mengacu pada pendapat Joyce dan Weil (1980) merupakan strategi yang dapat mengembangkan kemampuan berpikir dengan memanfaatkan pengalaman siswa sebagai titik tolak berpikir. Hakikat dari strategi ini adalah kemampuan berpikir seseorang sudah pasti diikuti oleh kemampuan mengingat dan memahami. Jika mengingat hanya melibatkan usaha penyimpanan informasi atau sesuatu yang telah dialami dan akan keluar disaat dibutuhkan. Memahami lebih membutuhkan pemerolehan apa yang didengar dan dibaca serta melihat keterkaitan antara aspek-aspek dalam memori. Untuk memiliki kemampuan mengingat dan memahami dibutuhkan kemampuan berpikir. Kemampuan berpikir tidak mungkin terjadi tanpa adanya memori. Bila seseorang kurang 
memiliki daya ingat (working memory) maka orang tersebut tidak mungkin sanggup menyimpan masalah dan informasi yng cukup lama. Jika seseorang kurang memiliki daya ingat jangka panjang (long term memory) maka orang tersebut dipastikan memiliki catatan masa lalu yang dapat digunakan untuk memecahkan masalah-masalah yang dihadapi pada masa sekarang.

Menurut Piaget seperti yang disitasi oleh Budiningsih (2005:39), salah satu tahap perkembangan anak menurut kognitifnya adalah tahap oprasional formal (umur 11/12-18 tahun) dimana priode ini setingkat usia siswa sekolah menengah. Ciri pokok perkembangan pada tahap ini adalah anak sudah mampu berpikir abstrak dan logis dengan menggunakan pola pikir "Kemungkinan atau membuat prediksi". Model berpikir ilmiah dengan tipe hipotetica-deductive dan inductive sudah mulai dimiliki anak, dengan kemampuan menarik kesimpulan, menafsirkan dan mengembangkan hipotesa. Pada tahap ini kondisi berpikir anak sudah dapat: (1) bekerja secara efektif dan sistematis, (2) menganalisis secara kombinasi. Dengan demikan telah diberikan dua kemungkinan penyebabnya, misalnya $\mathrm{C} 1$ (mengingat) dan $\mathrm{C} 2$ (memahami) menghasilkan $\mathrm{R}$ (response), anak dapat merumuskan beberapa kemungkinan, (3) berpikir secara proporsional, yakni menentukan macam-macam proporsional tentang C1, C2 dan R misalnya, (4) menarik generalisasi secara mendasar pada satu macam isi. Pada tahap ini mula-mula Piaget percaya bahwa sebagian remaja mencapai formal operations paling lambat pada usia 15 tahun. Tetapi berdasarkan penelitian maupun studi selanjutnya menemukan bahwa banyak siswa bahkan mahasiswa walaupun usianya telah melampaui, belum dapat melakukan formal operations.

Guru seharusnya memahami tahaptahap perkembangan kognitif para siswanya agar dalam merancang dan melaksanakan proses pembelajarannya sesuai dengan tahaptahap tersebut. Pembelajaran yang dirancang dan dilaksanakan tidak sesuai dengan kemampuan dan karakteristik siswa tidak akan ada maknanya bagi siswa. DRTA adalah strategi mengajar yang mengarahkan siswa dalam membuat prediksi mengenai bacaan dan membaca untuk mengkonfirmasi ataupun membantah prediksi mereka. Strategi ini mendorong siswa menjadi aktif dan pembaca yang kritis dengan meningkatkan pemahaman mereka. Tujuan penggunaan strategi ini adalah untuk melatih siswa untuk berkonsentrasi dan "berpikir keras" guna memahami isi bacaan secara serius (teacher vision,2011)

Adapun tujuan strategi Directed Reading Thinking Activity (DTRA) secara lebih rinci adalah sebagai berikut: (1) mendorong siswa untuk menjadi pembaca aktif dan berpikir, (2) merangsang atau mengaktifkan pengetahuan siswa, (3) mengajak siswa memonitor pemahaman mereka atas bacaan yang mereka baca, (4) membantu menguatkan kemampuan membaca dan ketrampilan berpikir kritis siswa. Strategi DRTA dapat digunakan sebelum membaca, selama membaca dan setelah membaca. DRTA dapat digunakan secara individu, kelompok kecil dan keseluruhan kelas yang sudah diatur.

Adapun prosedur dari DRTA adalah sebagai berikut;

$\mathrm{D}$ (directed) $=$ Langsung. Guru secara langsung mengaktifkan siswa berpikir lainnya. Guru harus menggunakan pertanyaanpertanyaan terbuka untuk siswa secara langsung, agar mereka membuat prediksi tentang isi atau perspektif dari teks (misalnya, " Dengan melihat judul ini, apa yang anda pikirkan ?”)

$\mathrm{R}$ (reading) $=$ Membaca. Siswa membaca sampai poin yang telah ditentukan untuk berhenti. Guru kemudian meminta siswa dengan pertanyaa-pertanyaan tentang informasi dan meminta mereka untuk mengevaluasi prediksi mereka dan memperbaikinya jika diperlukan. Proses ini harus dilanjutkan sampai siswa telah membaca setiap bagian dari teks tersebut.

$\mathrm{T}$ (thinking) $=$ Berpikir. Pada akhir setiap bagian, siswa kembali melihat teks yang ada dan berpikir tentang prediksi mereka. Siswa harus memverifikasi atau memodifikasi prediksi mereka dengan menemukan pertanyaanpertanyaan pendukung dalam teks. Guru menanyakan hal-hal berikut : (a) apa pendapat Anda tentang prediksi Anda sekarang ?, (b) apa yang Anda temukan dalam teks untuk membuktikan prediksi Anda?, (c) apa yang Anda baca dalam teks yang membuat Anda mengubah prediksi Anda?

A (activity) $=$ Kegiatan. Kegiatan disini maksudnya adalah kegiatan atau aktivitas membaca, yang mana selama kegiatan pemahaman bacaan tersebut siswa langsung aktif dan guru sebagai fasilitator serta guru mitra sebagai pemantau kegiatan dan 
memperhatikan hasil belajar. Jika hasil belajarnya maksimal itu yang diharapkan tetapi jika tidak maka kegiatan tersebut bisa diulang kembali.

Strategi ini bukan hanya sekedar model pembelajaran yang diarahkan agar peserta didik dapat mengingat dan memahami berbagai data, fakta, atau konsep tersebut dapat dijadikan sebagai alat untuk melatih kemampuan dan berpikir siswa dalam menghadapi dan memecahkan persoalan. ( Sanjaya, 2006 : 223 ). Landasan psikologis strategi ini adalah aliran kognitif yang memandang hakekat belajar adalah peristiwa mental behavioral. Peristiwa mental merupakan perilaku manusia tidak semata-mata gerak fisik tetapi juga yang lebih penting adalah faktor pendorong yang menggerakkan fisik itu. Hal itu mengacu pada apa yang dikemukakan oleh Piaget ".....children have a built-in desire to learn". Manusia selamanya memiliki kebutuhan untuk belajar dan kebutuhan itulah yang mendorong manusia untuk berperilaku.

Berdasarkan kerangka teoretis dan kerangka berpikir serta penelitian yang relevan, maka dapat dirumuskan hipotesis tindakan dalam penelitian ini adalah : (1) Kemampuan memahami bacaan bahasa Inggris siswa kelas XI IPA siswa SMA Negeri 2 Binjai dapat meningkat setelah mengikuti pembelajaran pemahaman bacaan melalui penerapan strategi Directed Reading Thinking Activity (DRTA); (2) Keaktifan siswa kelas XI IPA SMA Negri 2 Binjai dapat meningkat setelah mengikuti pembelajaran pemahaman bacaan melalui penerapan strategi Directed Reading Thinking Activity (DRTA)

\section{METODE}

Penelitian ini dilaksanakan pada siswa kelas XI IPA di SMA Negri 2. Penelitian ini merupakan penelitian tindakan kelas yang dilaksanakan melalui tiga siklus untuk melihat dan memperbaiki pembelajaran bahasa Inggris melalui. Adapun yang dijadikan subjek penelitian ini adalah siswa kelas XI IPA 1 yang terdiri dari 36 siswa dengan komposisi 19 lakilaki dan 17 perempuan dan 1 orang guru mitra sebagai observer.

Selanjutnya adalah analisis data kualitatif digunakan untuk melihat perkembangan sikap dan keterampilan kognitif yang diperoleh dari hasil observasi keaktifan siswa dan hasil kemampuan keterampilan memahami bacaan siswa selama proses pembelajaran dengan menggunakan strategi DRTA. Untuk analisis kualitatif, data diperoleh dengan membuat kategori pengelompokan data berdasarkan mastery level sesuai dengan sistem penilaian yang ada di SMA Negeri 2 Binjai.

Tabel 1. Kategori Tingkat Penguasaan

\begin{tabular}{|l|c|c|}
\hline No. & $\begin{array}{c}\text { Tingkat } \\
\text { Penguasaan }\end{array}$ & Kategori \\
\hline 1. & $\geq 81$ & Sangat Baik \\
\hline 2. & $76-80$ & Baik \\
\hline 3. & $70-75$ & Sedang \\
\hline 4. & $66-69$ & Rendah \\
\hline 5. & $\leq 65$ & Sangat Rendah \\
\hline
\end{tabular}

Untuk analisis data kuantitatif yang diperoleh dari hasil tes siswa maka dapat dilihat sebagai berikut:

$$
\text { Skor }=\frac{\text { Jumlah jawaban benar }}{\text { Jumlah soal }} \times 100
$$

Rentang nilai:

$\mathrm{A}=\geq 81$ = Sangat Baik (dapat memahami dan dapat menjawab pertanyaan bacaan dengan benar)

$\mathrm{B}=76-80=$ Baik (dapat memahami dan dapat menjawab pertanyaan bacaan dengan berterima)

$\mathrm{C}=70-79=$ Sedang (cukup memahami dan dapat menjawab pertanyaan bacaan dengan berterima)

$\mathrm{D}=66-69=$ Rendah (kurang dapat memahami dan menajwab pertanyaan dengan berterima)

$\mathrm{E}=\leq 65$ =Sangat Rendah (tidak dapat memahami dan tidak dapat menajwab pertanyaan bacaan dengan berterima)

Indikator keberhasilan penelitian ini adalah peningkatan keterampilan memahami bacaan dalam bahasa Inggris yang ditunjukkan dengan ciri-ciri: para siswa menunjukkan interaksi yang aktif, keterlibatan siswa dalam berbagai kegiatan, sikap siswa yang antusias dan senang dalam belajar serta kepercayaan diri siswa yang meningkat dan peningkatan kemampuan memahami bacaan yang dilihat dari faktor kemampuan siswa mengekspresikan pengetahuan pemahamannya melalui kebahasaannya. Tindakan penelitian ini akan dihentikan apabila 70 persen siswa di kelas tersebut mendapatkan nilai $\geq 70$ dan telah menunjukkan keaktifan dan kemampuan memahami bacaan yang baik.

\section{HASIL DAN PEMBAHASAN}


Hasil

Peneliti bersama guru mitra diawal penelitian membuat perencanaan dalam melaksanakan penelitian tindakan tentang pemahaman bacaan pada pembelajaran reading siswa kelas XI IPA. Sebagai langkah awal, siswa diberikan tes awal (pre-test) untuk melihat kemampuan awal mereka. Dari hasil tes diperoleh nilai keseluruhan siswa adalah 2373 dengan nilai rata-rata adalah 65,92

Perolehan rata-rata ini masih rendah dari nilai ketuntasan yang diharapkan adalah $\geq$ 70. Nilai tertinggi yang diperoleh siswa adalah 80 oleh 2 orang siswa, sementara nilai terendah yang diperoleh siswa adalah 40. Atau kalau dilihat dari persentase hasil belajar siswa dapat disimpulkan bahwa 63,89\% (23 orang) siswa belum memenuhi standar nilai $\geq 70$. Hanya 13 orang siswa atau $36,11 \%$ yang telah mencapai standar ketuntasan penguasaan pemahaman bacaan.

Analisis kuantitatif hasil pre-test siswa dapat dilihat pada Tabel 2 dibawah ini.

Tabel 2. Hasil Pre-Test

\begin{tabular}{|l|l|c|c|}
\hline No & \multicolumn{1}{|c|}{ Kategori } & $\begin{array}{l}\text { Jumlah } \\
\text { siswa }\end{array}$ & $\begin{array}{l}\text { Persen } \\
\text { tase }\end{array}$ \\
\hline 1 & $\begin{array}{l}\text { Sangat baik } \\
(\geq 81)\end{array}$ & - & - \\
\hline 2 & Baik $(76-80)$ & 5 & 13,89 \\
\hline 3 & Sedang $(70-75)$ & 8 & 22,23 \\
\hline 4 & Rendah $(66-69)$ & 5 & 13,89 \\
\hline 5 & $\begin{array}{l}\text { Sangat rendah } \\
(\leq 65)\end{array}$ & 18 & 50 \\
\hline & Jumlah & $\mathbf{3 6}$ & $\mathbf{1 0 0}$ \\
\hline
\end{tabular}

Perhitungan Data Peningkatan Kemampuan Memahami Bacaan Siswa Siklus I dan Siklus II

Hasil belajar siswa setelah diberikan tindakan pada siklus I mengalami peningkatan dengan perolehan nilai rata-rata 72,19 . Hasil ini lebih baik dari pre-test. Namun belum mencapai indikator ketuntasan yang telah ditetapkan, hanya 22 orang siswa atau $61,11 \%$ dari total jumlah siswa dinyatakan telah mencapai nilai $\geq 70$. Hasil ini masih dinyatakan kurang, oleh karena itu perlu dilakukan peningkatan dan perbaikan agar hasil ini didapat benar-benar mencapai target yang telah ditentukan.

Analisis kuantitatif hasil belajar siswa dari siklus pertama dapat dilihat pada Tabel 3 di bawah ini.

Tabel 3. Analisis Observasi Kemampuan Memahami Bacaan Siklus I

\begin{tabular}{|l|l|c|c|}
\hline No & $\begin{array}{l}\text { Kategori } \\
\text { siswa }\end{array}$ & $\begin{array}{l}\text { Persen } \\
\text { tase }\end{array}$ \\
\hline 1 & $\begin{array}{l}\text { Sangat baik } \\
(\geq 81)\end{array}$ & 6 & 16,66 \\
\hline 2 & Baik ( 76-80) & 7 & 19,44 \\
\hline 3 & Sedang (70-75) & 9 & 25 \\
\hline 4 & Rendah ( 66-69) & 10 & 27,77 \\
\hline 5 & $\begin{array}{l}\text { Sangat rendah } \\
(\leq 65)\end{array}$ & 4 & 11,11 \\
\hline & Jumlah & $\mathbf{3 6}$ & $\mathbf{1 0 0}$ \\
\hline
\end{tabular}

Berdasarkan data tersebut maka penelitian ini dinyatakan telah mencapai indikator keberhasilan tindakan yaitu jika siswa memperoleh nilai kemampuan memahami bacaan $\geq 70$. Untuk lebih jelas hal ini dapat dilihat pada Tabel 4. berikut.

Tabel 4. Analisis Observasi Kemampuan Memahami Bacaan Siklus II

\begin{tabular}{|l|l|c|r|}
\hline No & Kategori & $\begin{array}{l}\text { Jumlah } \\
\text { siswa }\end{array}$ & Persentase \\
\hline 1 & $\begin{array}{l}\text { Sangat baik } \\
(\geq 81)\end{array}$ & 10 & 27,77 \\
\hline 2 & Baik ( 76-80) & 12 & 33,33 \\
\hline 3 & Sedang ( 70-75) & 9 & 25,00 \\
\hline 4 & $\begin{array}{l}\text { Rendah ( 66 - 69 } \\
\text { ) }\end{array}$ & 3 & 8,33 \\
\hline 5 & $\begin{array}{l}\text { Sangat rendah } \\
\text { ( } \leq 65)\end{array}$ & 2 & 5,55 \\
\hline & Jumlah & $\mathbf{3 6}$ & $\mathbf{1 0 0}$ \\
\hline
\end{tabular}

\section{Perhitungan Data Peningkatan Keaktifan} Siswa siklus I dan Siklus II

Begitu juga halnya dengan siswa yang aktif mengalamai peningkatan pada siklus I. Dari 36 siswa terdapat 24 siswa yang aktif atau sekitar 66,66\% siswa yang aktif dari nilai ketuntasan keaktifan yaitu $\geq 70$. Adapun hasil nilai keaktifan siswa dapat dilihat pada Tabel 5 berikut.

Tabel 5. Analisis Observasi Keaktifan Siklus I

\begin{tabular}{|l|l|c|c|}
\hline No & Kategori & $\begin{array}{l}\text { Jumlah } \\
\text { siswa }\end{array}$ & $\begin{array}{c}\text { Persen } \\
\text { tase }\end{array}$ \\
\hline 1 & Sangat baik & 2 & 5,55 \\
\hline 2 & Baik & 6 & 16,66 \\
\hline 3 & Sedang & 16 & 44,44 \\
\hline 4 & Rendah & 8 & 22,22 \\
\hline 5 & Sangat rendah & 4 & 11,11 \\
\hline & Jumlah & $\mathbf{3 6}$ & $\mathbf{1 0 0}$ \\
\hline
\end{tabular}


Selanjutnya tingkat keaktifan siswa juga mengalami peningkatan dari siklus sebelumnya yaitu 36 siswa terdapat 8 ( 22,22\% ) siswa yang berpredikat sangat baik, 17 $(47,22 \%)$ siswa berpredikat baik dan $8(22,22$ $\%$ ) siswa berpredikat sedang. Secara keseluruhan total siswa yang aktif pada siklus kedua ini yaitu 91,66\%.

Tabel 6. Analisis Observasi Keaktifan Siklus II

\begin{tabular}{|l|l|r|c|}
\hline No & Kategori & $\begin{array}{l}\text { Jumlah } \\
\text { siswa }\end{array}$ & Persentase \\
\hline 1 & Sangat baik & 8 & 22,22 \\
\hline 2 & Baik & 17 & 47,22 \\
\hline 3 & Sedang & 8 & 22,22 \\
\hline 4 & Rendah & 2 & 5,55 \\
\hline 5 & Sangat rendah & 1 & 2,77 \\
\hline & Jumlah & $\mathbf{3 6}$ & $\mathbf{1 0 0}$ \\
\hline
\end{tabular}

Peningkatan penguasaan pemahaman bacaan bahasa Inggris siswa mulai dari pelaksanan Pre-Test hingga dilaksanakan tindakan dan diakhiri dengan tes akhir pada setiap siklus I dan siklus II, maka dapat dijelaskan bahwa tingkat ketuntasan semua adalah $86,11 \%$ atau sebanyak 31 siswa telah tuntas dalam pembelajaran pemahaman bacaan melalui strategi Directed Reading Thinking Activity (DRTA), dan hasil peningkatan ini lebih jelasnya dapat dilihat pada Tabel $\quad 4.6$ dan Gambar 4.6 berikut.

Tabel 7. Selama Siklus Tindakan

\begin{tabular}{|l|l|r|c|}
\hline No & Kategori & \multicolumn{1}{|c|}{$\begin{array}{l}\text { Jumlah } \\
\text { Siswa }\end{array}$} & Persentase \\
\hline 1 & Pre-Test & 13 & 36 \\
\hline 2 & Siklus I & 22 & 61 \\
\hline 3 & Siklus II & 31 & 86 \\
\hline
\end{tabular}

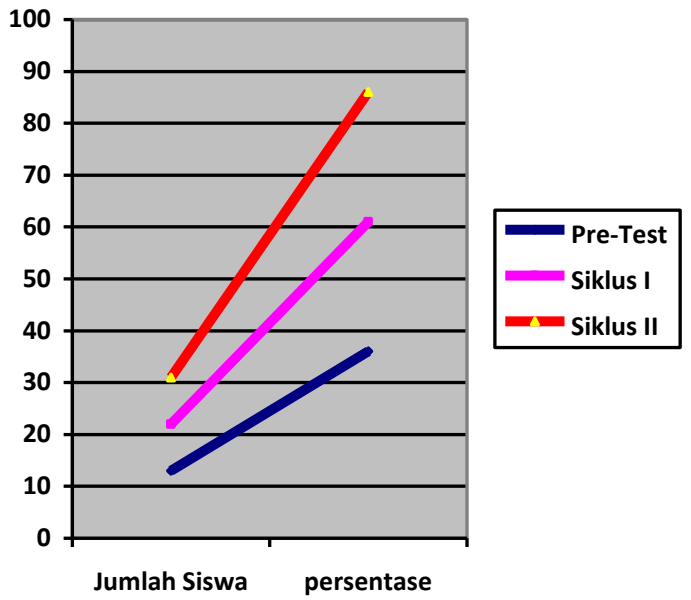

Gambar 1. Grafik siklus Tindakan

\section{Pembahasan}

Strategi pembelajaran DRTA bermanfaat bagi siswa sebagai salah satu strategi pembelajaran pemahaman bacaan yang sangat tepat dan menarik bagi siswa karena strategi ini sangat menarik minat dan perhatian siswa ketika siswa dituntut aktif dalam kegiatan memprediksi judul/gambar yang ditunjuk oleh guru yang dapat diungkapkan melalui kalimat atau kata. Setelah itu siswa diarahkan ke aktifitas membaca diam teks bacaan sambil mencocokan hasil prediksi mereka dengan teks yang mereka baca. Dalam aktifitas ini kegiatan scanning dilakukan oleh siswa. Selanjutnya ketika siswa diberi pertanyaan bacaan maka siswa melakukan kegiatan membaca secara scanning dan skimming.

Hakekat pemahaman sendiri menurut Thorndike sebagaimana disitasi oleh McNeil (1992:16), pemahaman berorientasi proses yang melibatkan aktivitas mental pembaca ketika berinteraksi dengan teks tertulis, pengukuran dilakukan dengan meminta pembaca menjawab pertanyaan bacaan. Dengan kata lain memahami bacaan dapat didefinisikan sebagai kemampuan menjawab pertanyaan pemahaman yang sesuai. Hal ini dikuatkan oleh penelitian Melvita, Santi (2009) dalam penelitiannya mengenai pengaruh strategi pembelajaran dan gaya belajar terhadap hasil belajar bahasa Inggris siswa SMA di kota Banda Aceh menunjukkan bahwa siswa yang diajar dengan menggunakan strategi DRTA memiliki hasil belajar yang lebih tinggi dibandingkan dengan siswa yang diajar dengan strategi Known-Want to know-Learned (KWL). 
Sedangkan gambaran mengenai keaktifan siswa terhadap pembelajaran dengan menggunakan strategi Directed Reading Thinking Activity (DRTA), Berdasarkan hasil pengamatan yang dilakukan oleh guru mitra (observer) maka proses pembelajaran baik pada siklus I dan Siklus II, terutama pada siklus II mengalami peningkatan keaktifan yang signifikan. Keaktifan dan kemampuan memahami teks sudah bertambah dan tidak kaku lagi hal ini terlihat dari ketidak canggungan mereka dalam mengekpresikan hasil prediksi mereka. Hal ini sesuai dengan yang dikemukan oleh Slavin (1995), mengemukakan bahwa siswa akan lebih aktif menemukan dan memahami konsep yang sulit apabila mereka dapat mendiskusikan dengan temannya.

Berdasarkan hasil observasi nilai hasil belajar yaitu nilai pemahaman bacaan dan nilai keaktifan siswa dapat disimpulkan sebagai berikut:

1. Strategi pembelajaran DRTA sangat bermanfaat bagi siswa dalam meningkatkan ketertarikan dan keaktifan siswa dalam pembelajaran pemahaman bacaan, ini ditunjukkan dari hasil pencapaian hasil belajar siswa yang tinggi.

2. Berdasarkan hipotesis strategi pembelajaran DRTA bahwa jika tingkat keaktifan siswa tinggi maka tingkat pemahaman siswa pun akan tinggi, atau jika tingkat pemahaman bacaan siswa tinggi otomatis tingkat keaktifan siswa pun menjadi tinggi. Namun berdasarkan temuan peneliti di lapangan bahwa hal ini sepenuhnya tidak tepat oleh karena ketrampilan yang diuji cobakan adalah ketrampilan memahami bacaan. Mungkin saja siswa yang agak pendiam tapi tingkat pemahamannya tinggi terhadap bacaan sehingga siswa tersebut dapat memahami dan menjawab pertanyaan bacaan atau tes dengan hasil yang memuaskan, sementara ada siswa yang tingkat keaktifanya tinggi namun tingkat pemahaman bacaannya rendah.

3. Motivasi siswa dalam pembelajaran bahasa Inggris setelah menggunakan strategi pembelajaran DRTA adalah tinggi.

4. Program tindakan kelas yang dilakukan kepada siswa sangat perlu untuk meningkatkan hasil belajar siswa dan keaktifan dalam belajar.

\section{PENUTUP}

Pertama, maka kegiatan pembelajaran bahasa Inggris diterapkan dengan strategi pembelajaran DRTA dan telah berhasil meningkatkan keaktifan siswa dalam belajar. Hal ini diketahui berdasarkan data observasi yang menunjukkan peningkatan keaktifan siswa selama siklus tindakan langsung. Pada siklus pertama terdapat $66,66 \%$ siswa yang aktif selama proses pembelajaran berlangsung. Selanjutnya jumlah ini meningkat pada siklus kedua menjadi 91,66 \% siswa yang aktif di kelas. Data tersebut membuktikan bahwa pembelajaran bahasa Inggris dengan penerapan strategi pembelajaran DRTA dapat memicu semangat dan minat siswa untuk aktif dalam mengikuti pelajaran terutama dalam ketrampilan membaca di kelas.

Kedua, kegiatan pembelajaran bahasa Inggris dengan menerapkan strategi pemahaman bacaan DRTA dapat meningkatkan kemampuan memahami bacaan pada siswa. Hal ini berdasarkan data yang menunjukkan peningkatan kemampuan memahami bacaan siswa sebelum dan sesudah tindakan. Berdasarkan pre-test sebelum tindakan terdapat $36,11 \%$ siswa memiliki kemampuan memahami bacaan $\geq 70$. Setelah dilaksanakan tindakan maka terjadi peningkatan yaitu pada siklus pertama terdapat $61,11 \%$ siswa yang memperoleh nilai $\geq 70$. Namun karena persentase tersebut belum memenuhi indikator keberhasilan tindakan maka dilakukan siklus kedua. Setelah siklus kedua dilaksanakan maka terjadi peningkatan kemampuan memahami bacaan siswa menjadi 86,11\% siswa yang memperoleh nilai $\geq 70$.

\section{DAFTAR PUSTAKA}

Arends. R.I. (2004). Learning to Teach. Sixth Edition. New York: Mc Graw-Hill Companies

Bloom, B. S. (1959), Taksonomy of Educational Objectives : The Classification

Of Educational Goals. Handbook I: Cognitive Domain. New York: Longman

Day, R.R dan Park, J. (2005). Developing Reading Comprehension Questions. http://nflrc.edu/rfl

Dick W, L.Carey and J.O Carey (2005). The Systematic Design of Instruction $6^{\text {th }}$ Edition. Florida: Pearson

Degeng, I N. S. (2000), Peran Teknologi Pembelajaran di Era Kesemrawutan 
Global. Makalah Seminar Nasional Teknologi Pendidikan. Jakarta: Forum komunikasi Mahasiswa pascasarjana Teknologi Pendidikan UNJ

Djuharie, O.S. (2005). Communicative Interactive English for the Second Grade of Senior High School 2. Untuk SMA Kelas XI. Semester 1 dan 2. Bandung: Yama Widya

Ekowati dan Mulyani 2003. Penulisan Karya Ilmiah dan Penelitian Tindakan Kelas. Jakarta : Depdiknas

Gagne, Robert M (ed). 1987. Instructional Technology : Foundation. London: LEA Publishers

Gagne, R.M \& Briggs J.L (1988). Principles of Instruction Design. New York:

Holt, Rinehalt and Winston

Gagne, R.M \& Briggs L.J \& Wagger, W.W. (1992). Principles of Instructional

Desain. New York: Holt, Rinehalt and Winston

Gunawan, A.S. (2004). Genius Learning Strategy : Petunjuk Praktis untuk Menerapkan Accelereted Learning, Jakarta: Gramedia Pustaka Utama

Hamalik, O. (2005). Perencanaan Pengajaran Berdasarkan Pendekatan Sistem. Jakarta: Bumi Aksara

Harmer, J. (2004). The Practice of English Language Teaching. Edinburgh: Pearson Education.

Herwono. (2005). Quantum Reading: Cara Cepat dan Bermanfaat untuk Merangsang Munculnya Potensi Membaca. Bandung: Mizan Learning Centre.

Jeremy Harmer, Addison Wesley. (1998). How to Teach Language. Longman Edition

Kral, T. (1993). Activities for teaching Reading. Selected Articles From The Creative English Teaching Forum Classroom 1989-1993 Activities.

Mc.Neil, J.D. (1992). Reading Comprehension: New Directions for Classroom Practice. 3rd Edition. USA : Harper Collins Publishers

Miarso, Y. (2004). Menyemai Benih Teknologi Pendidikan. Jakarta: Kencana.

Nasution, R. (2003). Pengaruh Metode Pembelajaran dan Motivasi Belajar terhadap Kemampuan Membaca Siswa dalam Mata Pelajaran Bahasa Indonesia. Tesis Tidak diterbitkan. Medan: Program Pasca Sarjana UNIMED MEDAN.

Nuttal, C. (1988). Practical Language Teaching: Teaching Reading Skills in a Foreign Language. Oxford : Heinemann International.

Prawiradilaga, Dewi Salma dan Siregar, Evelin. 2008. Mozaik Teknologi Pendidikan Jakarta : Kencana

Sally, et.al. (2005). Oxford Advanced Leaner's Dictionary. $7^{\text {th }}$ Adition. London:

Oxford University.

Sanjaya, Wina. (2005). Pembelajaran dalam Implementasi Kurikulum Berbasis

Kompetensi. Jakarta : Kencana Prenada Media.

Sardiman, (2009). Interaksi dan Motivasi Belajar Mengajar. Jakarta: Raja Grafindo Persada

Soedarso. (2004). Speed Reading. Sistem Membaca Cepat dan Efektif. Jakarta: Gramedia Pustaka Utama.

Sofa. (2008). Strategi Pembelajaran Membaca.File://G:\Lili CARI ILMU ONLINE BORNEO. Htm 26/02/2009.

Syaiful Bahri Jamarah dan Aswan Zain. (2006), Strategi Belajar Mengajar. Jakarta : Rineka Cipta.

Tarigan, Hendri Guntur. 1980. Menyimak : Sebagai Suatu Ketrampilan Berbahasa. Bandung : Angkasa

Tarigan, Hendri Guntur. 1980. Membaca: Sebagai Suatu Ketrampilan Berbahasa. Bandung : Angkasa

Tresni, K.K. 29 Agustus 2006. Liputan Khusus Kompas: The British Institute dan Pelajaran Bahasa Inggris. Kompas, hlm. 15.

Trianto. 2010. Mendesain Model Pembelajaran Inovatif- Progresif. Jakarta : Kencana

Uno, H. B. (2009), Model Pembelajaran (Menciptakan Proses Belajar Mengajar Yang kreatif dan Efektif). Jakarta: Bumi Aksara

Uno, Hamzah H. B (2009) . Perencanaan Pembelajaran Jakarta : Bumi Aksara

Wiratno, T. (2003). Mencerna Buku Teks Bahasa Inggris Melalui Pemahaman. Grammatika. Yogyakarta : Pustaka Belajar 